IZA DP No. 4898

Border Enforcement and Selection of Mexican Immigrants in the United States

Fernando A. Lozano

Mary J. Lopez

April 2010 


\title{
Border Enforcement and Selection of Mexican Immigrants in the United States
}

\author{
Fernando A. Lozano \\ Pomona College \\ and IZA
}

\author{
Mary J. Lopez \\ Occidental College
}
April 2010
IZA
P.O. Box 7240
53072 Bonn
Germany

Discussion Paper No. 4898

Phone: +49-228-3894-0

Fax: +49-228-3894-180

E-mail: iza@iza.org

\begin{abstract}
Any opinions expressed here are those of the author(s) and not those of IZA. Research published in this series may include views on policy, but the institute itself takes no institutional policy positions.

The Institute for the Study of Labor (IZA) in Bonn is a local and virtual international research center and a place of communication between science, politics and business. IZA is an independent nonprofit organization supported by Deutsche Post Foundation. The center is associated with the University of Bonn and offers a stimulating research environment through its international network, workshops and conferences, data service, project support, research visits and doctoral program. IZA engages in (i) original and internationally competitive research in all fields of labor economics, (ii) development of policy concepts, and (iii) dissemination of research results and concepts to the interested public.
\end{abstract}

IZA Discussion Papers often represent preliminary work and are circulated to encourage discussion. Citation of such a paper should account for its provisional character. A revised version may be available directly from the author. 
IZA Discussion Paper No. 4898

April 2010

\section{ABSTRACT \\ Border Enforcement and Selection of Mexican Immigrants in the United States}

Since 1986 the United States has made considerable efforts to curb illegal immigration. This has resulted in an increase in migration costs for undocumented immigrants. More stringent border enforcement either deters potential illegal immigrants from coming to the U.S., or moves the point of crossing for illegal immigrants from traditional crossing routes to more inhospitable routes. These changes are likely to place a heavier burden on illegal immigrant women as they are more likely to be kidnapped, smuggled, or raped when crossing illegally. If migration costs are not the same for all migrants, higher migrating costs may result in a change in the number and in the composition of immigrants to the United States. In the face of higher migration costs, only immigrants with relatively high expected benefits of migration will choose to migrate. Based on our theoretical model, we test for three empirical results that are associated with a stronger selection of immigrant women from Mexico relative to men as a result of higher migration costs: 1) A decrease in the relative flow of older and highly educated undocumented immigrant women relative to men; 2) A change in the skill composition of immigrant women to men; and 3) An increase in the average earnings of those groups most affected by increased migration costs. Using data from the 1990, 2000 Decennial Census, and from the 2006-2008 American Community Survey we empirically confirm these predictions.

JEL Classification: $\quad \mathrm{J} 1, \mathrm{~J} 2, \mathrm{~J} 3, \mathrm{~J} 6$

Keywords: immigration, gender, selection, border enforcement

Corresponding author:

Fernando A. Lozano

Department of Economics

Pomona College

425 N. College Ave

Claremont, CA 91711

USA

E-mail: fernando.lozano@pomona.edu

\footnotetext{
* We thank Eleanor Brown, Deborah Cobb-Clark, Sandy Darity, Marie Mora, Roberto Pedace and Carlos Vargas, as well as three anonymous referees for their comments. We also thank seminar participants at RSSS The Australia National University, Monash University and the Labor Seminar at UC Santa Barbara, and participants at the 2007 WEIA Meetings and at the 2007 SEA Meetings. All errors remain our own.
} 


\section{Introduction}

Mexico represents the largest source of migration to the United States with 32 percent of all immigrants originating from Mexico (Passel 2008). Prior to the 1980s, Mexican migrants to the U.S. were predominantly men, but there has since been a shift in the gender composition of Mexican immigrants (Marcelli and Cornelius, 2001). In 2008, the female share of the foreign-born population from Mexico stood at 43 percent (U.S. Census). As a result, economists have shifted attention towards the migration decisions and labor market outcomes of Mexican immigrant women relative to immigrant men. Recent work by Blau and Kahn (2007), for example, examines gender and assimilation of Mexican immigrants in the U.S. The authors find that Mexican immigrant women exhibit faster wage and employment convergence to U.S. native levels than Mexican immigrant men do. In addition, Chiquiar and Hanson (2005) examine the selection of Mexican immigrants in the U.S. They suggest that positive selection of immigrants may occur if migration costs are not constant across skill levels, but decrease with increasing levels of schooling. They find that based on observable skills, Mexican immigrant women in the U.S. fall in the upper tail of the Mexican wage distribution. That is, according to Chuiquiar and Hanson (2005), Mexican women are positively selected relative to those women that remain in the source country. This is in contrast to their finding that Mexican immigrant men are intermediately selected. While these studies reveal gender differences in the selection and assimilation of Mexican immigrants, the factors driving such gender differences continue to remain unexplored. The current study contributes to the literature by providing a framework to analyze gender differences in immigrant selection in the face of changing migration costs.

The past thirty years have been a period of increased unauthorized Mexican migration ${ }^{1}$. It is estimated that more than half of the 12.7 million Mexican immigrants currently residing in the U.S. are unauthorized (Passel 2008). Estimates also show that, since the 1990s, 80 to 85 percent of the annual migration from Mexico to the U.S. has consisted of unauthorized immigrants (Passel 2005). In response to this demographic shock, the US government heightened enforcement along the U.S.-Mexico border. The Immigration Reform and Control Act (IRCA) of 1986, which included both an employer sanction program and a border enforcement program, marked the beginning of a series of border enforcement policy changes. This was followed by

\footnotetext{
${ }^{1}$ For a review of the literature on unauthorized migration from Mexico see Hanson (2006).
} 
Operation Hold the Line in Texas, Operation Gatekeeper in California, and Operation Safeguard in Arizona, where a significant amount of resources were devoted to controlling undocumented immigration and making it more difficult for migrants to cross through the traditional crossing channels. For example, between 1992 and 2007, the annual budget for border enforcement operations increased from $\$ 400$ million to $\$ 1.94$ billion (Hendricks 2007). In addition, new technological resources such as night vision cameras, ground sensors, and infrared surveillance equipment were adopted (Eschbach et al. 2003, Hendricks 2007).

However, research shows that despite the substantial additional resources employed for border policing, there is no concluding evidence that the border enforcement policies of the 1990s were successful in reducing undocumented immigration. In fact, the enforcement policies either created a large diversion effect or increased the length of time spent in the U.S. (Angelluci 2005, Sorensen and Carrion-Flores 2006). That is, more stringent border enforcement has resulted in a shift of migrant traffic from urban areas to inhospitable areas, such as the Arizona desert, which have created significant consequences for migrants (Hendricks 2007). For example, the General Accounting Office (GAO, 2006) reports that from late 1998 through 2005 the number of migrant border-crossing deaths doubled. The increase in deaths was more dramatic for women, where the number of deaths increased from 9 percent in 1998 to 21 percent in 2005. Reports by Mexico's Secretaria de Relaciones Exteriores (Foreign Affairs Ministry) show that more than 3,500 immigrants died while crossing the border in 2009, and 58 percent of them are women (Hernandez, 2009). There have also been reports of increased violence along the border such as gunfights, hijackings, rapes, and assault (Wall St. Journal Oct. 2007). Thus, it appears that the stringent border enforcement policies of the past 20 years have led to an increase in migration costs with the costs falling predominantly on immigrant women.

Evidence of the greater costs can be seen in Figure 1A, which shows average coyote prices for household heads that migrated to the U.S. illegally. ${ }^{2}$ Not only have coyote costs increased since the 1990s, but the costs have been greater for women than for men. Donato and Patterson (2004) find that following the implementation of the IRCA, women were more likely than men to use coyotes to cross the border. The extensive use of coyotes by women and the dramatic increase in deaths among women crossing the border may be an indication of the greater risks that women face relative to men when crossing the border.

In this paper, we examine the extent to which greater migration costs, as a result of more stringent border

\footnotetext{
${ }^{2}$ See also Gathmann (2004) who finds evidence that coyote prices are higher for migrants during years of expanded border enforcement.
} 
enforcement, has changed the composition of Mexican immigrant women relative to Mexican immigrant men. Our main hypothesis is that the stringent border enforcement policies of the past 20 years have led to an increase in migration costs, which may in turn have affected the composition of Mexican immigrants in the U.S. More importantly, we argue that these costs, which include greater physical risks in crossing the border and greater psychic costs of being unable to return temporarily to the source country, fall more heavily on undocumented immigrant women. A change in the composition of Mexican immigrant women relative to men is evidenced by a change in their demographic characteristics and in a change in their labor market outcomes. In particular, we develop a theoretical framework which allows us to test whether higher migration costs that fall predominantly on women will reduce the number of high skilled, older immigrant women, relative to demographically equivalent men. In addition, we show that the changes in earnings across different cohorts of immigrants from Mexico are greatest among these groups, suggesting stronger selection of immigrants.

\section{Theoretical Framework}

It is commonly believed that most immigrants in the U.S. posses little formal skills. For example, Borjas (1987) predicts that immigrants with low schooling levels will be drawn from countries where low-skill labor is abundant and income inequality is large, as their returns from migration are high. In contrast to low skilled workers, returns to education will be relatively high for highly educated workers when their skills are scarce in the source economy. Therefore, Borjas' analysis suggests that the source country distribution of skills and income will create incentives for low-skill workers to migrate while high-skill workers remain in the source country.

Borjas' empirical analysis supports his predictions, where immigrants from countries where unskilled labor is abundant tend to have worse labor market outcomes in the US economy than other immigrants. Similarly, Cobb-Clark (1993) addresses the issue of self-selection among immigrant women and her findings support Borjas' negative selection hypothesis. She shows that immigrant women from countries with high levels of GDP, low income inequality, and low returns to education tend to exhibit higher U.S. wages. However, Chiquiar and Hanson (2005) argue that if migration costs are not held constant, but decrease with skills, 
then migrants from countries with high levels of income inequality can be negatively selected or positively selected. The authors suggest that migration costs may decline with schooling if highly educated migrants are more able to comply with bureaucratic requirements or face fewer credit constraints compared to less skilled migrants. Incorporating differences in migration costs across men and women into the framework, we hypothesize that migration costs may vary by gender with female migrants incurring greater costs than men. Thus, a resident of Mexico of gender $g$ in an age category indexed by $j$ and a skill level indexed by $i$ will migrate to the U.S. in year $t_{0}$ if and only if:

$$
\sum_{t=a_{0}}^{a_{N}}\left(\frac{1}{1+\delta}\right)^{t-t_{0}} E\left(w_{g j i t}^{U S}(a)-w_{g j i t}^{M e x}(a)\right)-C_{g j i t}(a)>0
$$

The summation starts with $t_{0}$ which is the age in which the migrant comes to the U.S. and ends at $t_{N}$ which is the age when the immigrant retires from work or returns to the source country - the length of the "labor migration" is $t_{N}-t_{0}$. The first term in the inequality is the difference in expected earnings between Mexico and the US. This difference is compounded across time with the discount factor $\delta$. The second term in the inequality is the cost of migration, which here is assumed to be fixed and imposed on the migrant at the time of migration. While we assume that costs within a gender-age-skill group are constant, we assume that the costs can vary across gender groups. Note that both costs and wages depend on the ability of the potential immigrant which is denoted by $a$.

The top panel in Figure 2 presents the costs and benefits of migration. We assume that $\frac{\partial C}{\partial a}<0$ and $\frac{\partial w}{\partial a}>0$, and that $a$ is a measure of the distribution of ability in Mexico: $a \sim$ uniform $[0,1]$ and it is known to the potential migrant. This distribution is depicted in the bottom panel of Figure 2. For any given time, only immigrants within a gender-age-skill group with an ability level $a \geq a^{*}$ will choose to migrate and those with ability level $a<a^{*}$ will stay in Mexico. The equilibrium is depicted in the top panel of Figure 2 where the expected benefit from migration equals the cost from migration at level of ability $a^{*}$, again only $1-a^{*}$ potential immigrants will choose to migrate. An increase in the migration costs due to more stringent border enforcement will shift the cost function to the right for every ability level, as these costs have gone up. This shift is represented in Figure 2 with the shift from $\mathrm{C}(\mathrm{a})$ to $\mathrm{C}^{\prime}(\mathrm{a})$, and now the new equilibrium is at the ability level $a^{* *}$ and only immigrants with a level of ability above that will choose to migrate. The 
distance between $a^{*}$ and $a^{* *}$ represents the number of immigrants who would have migrated under the old cost levels, but choose not to now under the higher cost levels.

There are two major reasons why migration costs may vary by gender. First, women's migration responses may be more sensitive to changes in immigration enforcement since they are more vulnerable to the physical dangers of crossing the border illegally. As a result of the border policies of the 1990s, women now face a greater probability of becoming lost and being robbed, raped, or kidnapped because they are forced to cross the border in more inhospitable regions. Falcón (2007) documents multiple instances of rape along the U.S.-Mexico border. Second, migrant women are more likely than men to make multiple trips across the border because they act as the main caretakers of their children or elder parents. Hondagneu-Sotelo and Avila (2007) suggest that as the number of female-headed households in Mexico and Central America has increased, more women are leaving their children in the source country in order to seek employment in the U.S. These women return home to visit their children when it is financially and logistically possible. Any U.S. immigration policy that increases the costs of crossing the border will also make it more difficult for these migrants to return to Mexico temporarily in the event of a family emergency. As a result, the psychic costs involved with being far from one's family and unable to return to the source country on a temporary basis may fall more heavily on women. For example, Reyes (2004) finds that there was a sharp decline in the probability of return trips in the late 1990s and suggests that it is a result of greater border enforcement.

Figure 1B shows the duration of stay for the average migrant's first undocumented trip to the U.S. Not only do women have a longer duration of stay in the U.S. than men, but the increase in the duration of stay over time has been more pronounced for women than for men. Between 1982 and 2008, the duration of stay increased by slightly over 43 months for undocumented Mexican men, but by almost 60 months for undocumented Mexican women. If we assume that returning temporarily to the source country in order to be with parents, children, or other family members is desirable, then without loss of generality this cost can also increase with $t$. Our premise is that border enforcement makes $C_{w o m e n, j i t}>C_{m e n, j i t}$, therefore a female immigrant should perceive a higher expected wage gain from migrating than an immigrant male.

It is impossible to directly estimate the effect that increased border enforcement has on the selection of undocumented immigrants into the United States. Ideally, we would need to observe all potential immigrants in Mexico and assign them to different border patrol scenarios, then we would need to evaluate whether 
the ability of immigrant women changed across different border enforcement scenarios. Of course this is empirically impossible. Instead, we use equation (1) to predict how different immigrant groups would behave with an increase in costs. Several inferences can be derived from equation (1). First, as migration costs increase, the number of immigrants should decrease, ceteris paribus ${ }^{3}$, as the new costs will be greater than the expected benefits for some potential migrants.

Second, the gains in earnings from migration are accrued across the expected length of the migration. Therefore, equation (1) predicts that the sum of relative earnings in the U.S. is greater for younger workers than for older workers, making migration more attractive to younger workers. This is consistent with empirical evidence that shows that migration rates from Mexico are highest for young adults (Chiquiar and Hanson 2005). As costs increase, we would expect holding all else constant to see fewer Mexicans migrating to the U.S., both old and young. However, the slowdown in migration should be larger for older workers than for younger workers.

Third, following Borjas (1987), since Mexico is abundant in less educated labor and the U.S. is abundant in highly educated labor, then the relative earnings for highly educated workers in Mexico are greater than the relative earnings of these same workers were they to migrate to the U.S. Under this assumption, equation (1) suggests that the expected gains in earnings from migration will be greater for less educated Mexican immigrants than for highly educated Mexican immigrants. As a result, less educated Mexicans will be more likely to migrate to the U.S. than highly educated Mexicans. An increase in migration costs holding everything else constant will result in fewer Mexicans migrating to the U.S., both low and highly educated. However, since the benefit of migration is smaller for highly educated Mexicans, an increase in costs will result in a decrease among the highly educated that is greater than among the lower educated. Note that this is consistent with the relative deprivation hypothesis suggested by Stark and Taylor (1989) where potential immigrants decide to migrate as a function of the gains from migration relative to a reference group in the source country. Finally, if border costs fall more heavily on women, then we would expect to observe that the decrease in the migration of skilled and older workers are larger for women relative to men.

\footnotetext{
${ }^{3}$ Of course there will be factors in the source and host economy that will determine migration flows regardless of border enforcement, but theoretically we hold these constant.
} 


\section{Data and Descriptive Patterns}

To evaluate changes in the composition of Mexican immigrants, we use data from the 5-percent Integrated Public Use Microdata Series (IPUMS) for the Census years 1990 and 2000 and for the American Community Survey years 2006 through 2008. ${ }^{4}$ We restrict our analysis to individuals between the ages of 16-64 who were born in Mexico. In order to isolate the undocumented population, we further restrict our sample in most of our analysis to recent immigrants or those who migrated within 5 years of the survey year. Recent immigrants are more likely to be illegal immigrants (Hanson 2006). We also focus much of our analysis on single immigrant men and women. As marriage and fertility rates have declined within several countries, the prevalence of "tied movers" is diminishing and women are more likely to migrate in response to economic incentives. In addition, we restrict our sample to adult immigrants or those individuals that migrated to the U.S. at the age of 16 years or older. This restriction ensures that our sample consists of immigrants who received most of their schooling abroad and not in the U.S. As we are interested in all immigrants, we also do not exclude the self-employed from our sample. All monetary values are in real dollars.

Census data does not include information on legal status. Thus even after restricting the sample to recent immigrants, our sample may still include both undocumented and legal immigrants. After evaluating various sources of data on undocumented immigrants, Hanson (2006) argues that there is currently no reliable source of data on the undocumented. Even the Mexican Migration Project (MMP), which is a rich household survey conducted in winter months in rural communities in Mexico and includes data on legal status, suffers from several problems. First, the MMP is not representative of Mexico, Mexican immigrants, or the undocumented population in the U.S. (Hanson 2006, Durand and Massey 2004). The MMP suffers from sampling bias in that it is comprised of only rural households and households residing in communities with high migration propensities. The MMP communities have extensive experience crossing the border and have strong ties with coyotes. Thus, the MMP migrants may be less responsive to shocks in border enforcement policies that raise the costs of migration (Hanson 2006). In addition, only migrants who have returned to Mexico are surveyed directly. Migrants currently residing in the U.S. are not direclty surveyed. Second, Hanson (2006) documents that the seasonal migrants represented in the MMP are not consistent with the demographic and

\footnotetext{
${ }^{4}$ The analysis does not include 1980 data as a result of the impact that the Immigration Reform and Control Act (IRCA) might have on the flow of recent immigrants.
} 
labor market characteristics of the undocumented population found in other data sources. Finally, the MMP suffers from a gender bias in that the sample of undocumented immigrants is overwhelmingly comprised of immigrant men. This hinders our ability to study trends in the migration patterns of women relative to men across various age and schooling groups.

While it is commonly believed that the undocumented are not represented in household Census data, estimates using the residual method show that the number of immigrants enumerated in the Census is too large for them all to be legal (Hanson 2006). ${ }^{5}$ In addition, recent estimates using Census data suggest that 56 percent of the Mexican immigrant population is undocumented (Passel 2005). As the costs of legal migration have also risen (longer wait times for permanent legal residence visas), more than half of the new immigrants from Mexico are those adjusting from illegal status to permanent legal residence status (Hanson 2006). Therefore, even the legal immigrants represented in the Census may have entered the U.S. unlawfully. Despite the problems associated in capturing a representative sample of undocumented immigrants in both the Census and the MMP, the large number of Mexican immigrant women represented in the Census makes it the preferable database for this study.

Along this paper we will compare outcomes of Mexican immigrants with other Latin American immigrants or Mexicans who choose to stay in Mexico. Because greater U.S.-Mexico border enforcement may influence the migration decision of all potential migrants, we assume that Mexican immigrants would be the group most directly affected by greater migration costs. Thus, we would expect that any changes in migration patterns will be stronger for Mexican immigrants compared to other Latin American immigrants. We use the Decennial Census Data to evaluate labor market outcomes of Latin American immigrants in the U.S. In addition, we present information on labor market outcomes for Mexicans who choose to stay in Mexico. To evaluate the labor market outcomes of non-migrants in Mexico, we use data from the Mexican Decennial Census Data (available in the IPUMS collection) and the Encuesta Nacional Ingreso Gasto de los Hogares (ENIGH). The ENIGH is a household income and expenditure survey conducted regularly among a nationally representative sample of Mexican households. This survey contains demographic and labor market information for each member of the household. Again, we restrict our analysis to individuals between the ages of $16-64$.

\footnotetext{
${ }^{5}$ The residual method takes the difference between the measured foreign-born population and the sum of past legal immigrant flows.
} 
Summary statistics for the sample of Mexican immigrants are shown in Table 1. As Table 1 reveals, Mexican immigrant women earn approximately 10 percent less than what Mexican immigrant men earn. They are also much less likely than men to be employed, more likely to be married, and are older than immigrant men. The average years of schooling is also slightly higher for Mexican immigrant women. Summary statistics are also included in Table 1 when the sample is restricted to other immigrants from Latin America and the Caribbean. First, the gender differences that we observe among Mexican immigrants are also evident among other Latin American immigrants. Second, wages, years of schooling, and age are all slightly greater for other Latin American immigrants than for Mexican immigrants.

Figure 3 shows the proportion of female immigrants across time for Mexican immigrants and for other immigrants from Latin America and the Caribbean. If the costs of migration increase and if these weigh more heavily on immigrant women, then we would expect to observe that the proportion of women migrating is declining. In addition, given that the majority of undocumented immigrants are from Mexico and because Mexican immigrants are more directly impacted by more stringent U.S.-Mexico border enforcement, we would expect to see that the decline in the proportion of women migrating is larger for Mexican immigrants than for other Latin American immigrants. Yet the figure shows that the proportion of women is declining slightly over time for both Mexican immigrants and other Latin American immigrants and the decline is similar for both groups. As we fail to see an statistically greater decrease in the proportion of female Mexican immigrants across time than for other Latin American immigrants, we now turn to see if the age and education characteristics of these immigrants differ as equation (1) above would predict.

Figure 4A shows the proportion of female immigrants by age category. Higher migration costs should result in lower proportions of women migrating for all age categories. However, the slowdown should be larger for older immigrants. Since 1990, the proportion of female immigrants from Mexico has decreased the most among older immigrants (those 38 years and older). The proportion declined only slightly for the youngest immigrants. Thus over the same time that U.S. border policies have raised the costs of crossing the border, we observe a decrease in the proportion of older immigrant women relative to younger immigrant women. We also compare the proportion of female Mexican immigrants in the U.S. to other Latin American immigrants in the U.S. (see Figure 4B) While, the proportion of older female Latin American immigrants has also declined over time, the decline is much less pronounced than what we observe for Mexican immigrants. 
Figure 5A shows the proportion of female immigrants from Mexico by education categories. While the proportion of women has decreased over time among Mexican immigrants with less than 9 years of education, it has remained relatively unchanged among college graduates. This is in contrast to what is predicted with Equation (1), which suggests that the ratio would fall more among highly educated immigrants than among less educated immigrants. We also compare the trend of Mexican immigrants in the U.S. to residents in Mexico. Figure 5B shows that the proportion of female college graduates has increased while the proportion of women with less than 9 years of schooling has declined only slightly. The trends observed in Figure 5B are not surprising given that schooling in Mexico over the past two decades has increased. In addition, LopezAcevedo (2006) finds that schooling increased in Mexico between 1988 and 2002, but that Mexican women increased their educational attainment more than men. Figure 5B shows that as schooling has increased in Mexico, it seems that more highly educated migrants are choosing to stay in Mexico. That is, if we compare the trends between Mexicans who stay in Mexico and those who migrate, the fact that the proportion of highly educated immigrants in the U.S. is not increasing may be a consequence of the prediction from our model (and suggests that immigrants are not randomly drawn from the population). In the next section we describe our empirical strategy to explore these hypothesis formally.

\section{Empirical Strategy}

This paper attempts to determine if changes in the migration patterns of women are the result of changes in the migration costs since the 1990's. While migration costs can influence the decision to migrate, other push and pull factors may also be responsible for the migration patterns of Mexican immigrants. For example, trade liberalization has resulted in an increase in income inequality in Mexico. Greater income inequality may be the factor driving migration from Mexico to the U.S. In addition, the 1990's marked one of the longest U.S. economic expansions. Thus, the economic expansion may have pulled individuals from Mexico to the United States. In order to control for the changes in the push and pull factors that influence the decision to

migrate, we employ a difference-in-difference and a difference-in-difference-in-difference methodology. If we assume that changes in the Mexican labor market affect the decision to migrate the same for all Mexicans and that changes in the U.S. labor market influence the decision to migrate the same for all migrants, then 
the double and triple estimators will control for the general changes in the source country and host country labor markets. That is, we control for push factors, factors in the Mexican economy by comparing outcomes of Mexican immigrant women with the outcomes of Mexican immigrant men. In addition, we control for pull factors, factors in the US economy, by comparing the outcomes of Mexican immigrant women with other Latin American immigrant women.

Our empirical strategy will be based on using the variation in equation (1) across different gender, age and skill groups to show that the decision to migrate for women is more sensitive to migration costs than it is for men. In particular, our model predicts the following two outcomes. First, a change in costs will affect the migration decision of older potential migrants more than of younger migrants, and costs that differ across gender will result in fewer older women migrating relative to men in the same age group. Thus, in order to test whether the flows of older immigrant women relative to men have decreased during the period of stringent border enforcement, we estimate the following probability equation:

$$
\begin{aligned}
P\left(A_{i t}=1\right)= & \sum_{a=1}^{3}\left(\beta_{a}^{\text {mex }} F_{i t} \times Y_{a i t} \times M e x_{i t}\right)+\sum_{a=1}^{2}\left(\gamma_{a}^{\text {mex }} M_{i t} \times Y_{a i t} \times M e x_{i t}\right)+ \\
& \sum_{a=1}^{3}\left(\beta_{a}^{\text {oth }} F_{i t} \times Y_{a i t} \times O t h_{i t}\right)+\sum_{a=1}^{3}\left(\gamma_{a}^{\text {oth }} M_{i t} \times Y_{a i t} \times O t h_{i t}\right)+\epsilon_{i t}
\end{aligned}
$$

where $A_{i t}$ is a dummy variable that takes a value of one if the immigrant belongs to each age category. The three age categories included in this analysis are 18-27, 28-37, and 38 and older. Equation (2) is estimated separately for each age category. Dummy variables for female and male, $F_{y i t}$ and $M_{y i t}$ respectively, are interacted with year dummy variables $Y_{a}$, and the nativity dummy variables Mex and Oth. The three year dummy variables $Y_{1}, Y_{2}$, and $Y_{3}$ are for the years 1990, 2000, and 2007, respectively. The variable Mex takes the value equal to one if the individual is a migrant from Mexico and the variable Oth takes the value equal to one if the individual is a migrant from other Latin American countries or the Caribbean. The omitted category is the number of male immigrants from Mexico in 1990. We are interested in testing whether we observe fewer women migrating relative to men in the same age group over time. We begin with a first difference which compares the outcomes of immigrants within gender across time. For example, the first 
difference estimates outcome of for Mexican women across time and is $\beta_{3}^{m e x}-\beta_{1}^{m e x}$. The second difference, estimates the outcomes of immigrants, across gender, but within nativity across time, in the case of Mexican immigrants $\beta_{3}^{\text {mex }}-\beta_{1}^{\text {mex }}-\gamma_{3}^{\text {mex }}$. Note that if push factors are similar for men and women, then this estimate should be net of any push factors. The third difference estimates the outcomes of immigrants, across gender and across nativity groups, that is: $\left(\beta_{3}^{\text {mex }}-\beta_{1}^{\text {mex }}-\gamma_{3}^{\text {mex }}-\left(\beta_{3}^{\text {oth }}-\beta_{1}^{\text {oth }}-\gamma_{3}^{\text {oth }}\right)\right)$. Again, if we assume that pull factors are constant between immigrants from Mexico and immigrants from other Latin American countries, then these estimates across time will net them out.

It is worthwhile to discuss our assumption that push factors are constant for men and women in Mexico. Clearly, Figure 5B shows that the number of Mexican women who graduate from secundaria and preparatoria has increased during the last 20 years. Similarly, Figures $6 \mathrm{~A}$ and $6 \mathrm{~B}$ show that the gender earnings gap in Mexico has also increased, while the employment to population ratio has decreased. The widening of the gender wage gap in Mexico during this period is consistent with the results observed by Artecona and Cunningham (2002) and Juhn et al. (2006). Thus, if immigrant women from Mexico are randomly drawn from the population in Mexico, then higher educational attainment among women in Mexico will be associated with more highly educated women migrating to the U.S. - which is the opposite of our prediction. In addition, greater gender earnings gaps will again be associated with more women migrating to the U.S., as it widens the gap between expected earnings in both countries. Again, this is the opposite of our prediction. Therefore, while the assumption that push factors are similar across gender is problematic, we argue that any bias that results from this assumption will attenuate our estimates of the second difference towards zero.

Similarly, our assumption that pull factors are the same for all migrants may be problematic if: a) other Latin American immigrants are different than immigrants from Mexico, or b) other Latin American immigrants faced a similar increase in migrating costs during the same period of greater border enforcement. Recall that Table 1 shows that other Latin American immigrants are on average more educated and earn higher wages than Mexican immigrants. We control for age, education, and occupation differences that will net out some of the differences between these groups. In addition, it is clear that some immigrants, particularly Central Americans, face similar enhanced migration costs as a result of increased border enforcement. In fact, if costs of migrating through Mexico have increased as well during the last 20 years, then Central American immigrant women will face migration costs that are greater than the costs faced by Mexican 
immigrant women. While this is a possibility, any "pollution" of this type in our control group will again attenuate the third difference towards zero ${ }^{6}$.

In addition to estimating changes in migration by age category, we are also interested in how changes in migration costs will affect the migration of highly educated potential immigrants relative to less educated potential immigrants. Again, our model predicts that higher costs levied on women will result in fewer highly educated immigrant women migrating to the U.S. relative to highly educated men. In order to test whether the flows of high skilled immigrant women relative to men have decreased we estimate the following probability equation:

$$
\begin{aligned}
P\left(E_{i t}=1\right)= & \sum_{a=1}^{3}\left(\beta_{a}^{\text {mex }} F_{i t} \times Y_{a i t} \times \operatorname{Mex}_{i t}\right)+\sum_{a=1}^{2}\left(\gamma_{a}^{\text {mex }} M_{i t} \times Y_{a i t} \times M e x_{i t}\right)+ \\
& \sum_{a=1}^{3}\left(\beta_{a}^{\text {oth }} F_{i t} \times Y_{a i t} \times O t h_{i t}\right)+\sum_{a=1}^{3}\left(\gamma_{a}^{\text {oth }} M_{i t} \times Y_{a i t} \times O t h_{i t}\right)+\epsilon_{i t}
\end{aligned}
$$

where $E_{i t}$ is a dummy variable that takes a value of one if the immigrant belongs to each education category. The four education categories included in the analysis are 0-8 years, 9-11 years, 12-15 years, and more than 16 years of schooling. Again, we are interested in the difference-in-difference-in-difference estimator $\left(\beta_{3}^{\text {mex }}-\beta_{1}^{\text {mex }}-\gamma_{3}^{\text {mex }}-\left(\beta_{3}^{\text {oth }}-\beta_{1}^{\text {oth }}-\gamma_{3}^{\text {oth }}\right)\right)$.

Our final empirical test involves the labor market outcomes of immigrants in the United States. If an increase in border enforcement results in a change in the composition of immigrants, then we would expect to see that observed wages should increase among the demographic groups affected the most by the more stringent border controls. In this case, we would expect to see that the wages for older and highly educated women migrating from Mexico should be increasing relative to the wages of demographically equivalent men from Mexico. As argued previously, to control for the overall reduction in the gender wage gap observed in the United States (Blau and Kahn, 2006 or Weinberger and Kuhn, 2009) we use the evolution of gender differences in earnings for other Latin American immigrants as a control group. Thus, we should observe that the secular change in the decline of gender wage gaps in the United States is similar across demographically equivalent

\footnotetext{
${ }^{6}$ The other natural control group, other US born Hispanics is perhaps even more problematic, and empirically unfeasible. This workers do not choose whether or not to migrate, they have all their education in the US, and computationally we cannot compare them with different arrival cohorts of immigrants
} 
Mexican and Latin American immigrants. If we observe differences across demographically equivalent groups then these differences may be attributed to a difference in the selection of immigrants.

Our baseline wage equation will compare the outcome of immigrants who arrived before 1984 and immigrants who arrived after 2000:

$$
\begin{aligned}
& Y_{i t}=\sum_{c=1}^{6}\left(\beta_{c}^{\text {mex }} F_{y i t} \times C_{i t} \times M e x_{i t}\right)+\sum_{c=1}^{6}\left(\gamma_{c}^{\text {mex }} M_{y i t} \times C_{i t} \times M e x_{i t}\right)+ \\
& \sum_{c=1}^{6}\left(\beta_{c}^{\text {oth }} F_{y i t} \times C_{i t} \times O t h_{i t}\right)+\sum_{c=1}^{6}\left(\gamma_{c}^{\text {oth }} M_{y i t} \times C_{i t} \times O t h_{i t}\right)+x_{i t}^{\prime} \theta+\epsilon_{i t}
\end{aligned}
$$

where $\mathrm{Y}$ represents either the $\log$ of hourly wages of individual $i$ in year $t]^{7}$. $C$ is a dummy variable for arrival cohort where:

$$
C_{i t}=\left\{\begin{array}{cc}
1 & \text { immigrant } i \text { in survey } t \text { arrived before 1985 } \\
2 & \text { immigrant } i \text { in survey } t \text { arrived 1985-1987 } \\
3 & \text { immigrant } i \text { in survey } t \text { arrived 1988-1991 } \\
4 & \text { immigrant } i \text { in survey } t \text { arrived 1992-1997 } \\
5 & \text { immigrant } i \text { in survey } t \text { arrived 1996-2000 } \\
6 & \text { immigrant } i \text { in survey } t \text { arrived after } 2000
\end{array}\right.
$$

and $x_{i t}^{\prime}$ is a set of observable characteristics that include controls for education, age, age squared, state of residence, year, year interacted with gender, years in the U.S., and occupation. Again, as in the previous section we are interested in the difference-in-difference-in-difference estimator $\left(\beta_{6}^{\text {mex }}-\beta_{1}^{\text {mex }}-\gamma_{6}^{\text {mex }}-\left(\beta_{6}^{\text {oth }}-\right.\right.$ $\left.\left.\beta_{1}^{\text {oth }}-\gamma_{6}^{\text {oth }}\right)\right)$. Finally, and as mentioned above, we repeat equation (4) above for different subgroups. Our theory predicts that the difference-in-difference-in-difference estimator will be greatest among the groups most likely to be affected by border enforcement, older and highly educated women from Mexico ${ }^{8}$.

\footnotetext{
${ }^{7}$ We exclude observations for the 2008 ACS as we do not have any income information.

${ }^{8}$ Finally, it must be made clear that equations (2) and (3) are estimated with the sample of recent immigrants only (those who have been in the United States for 5 or less years). This is because our interest is to measure flows of immigrants. In contrast, equation (4) is estimated using the complete sample of single-never married immigrants, and we control for U.S. experience. We do this in the spirit of having estimates that are comparable to those in the literature based on Borjas (1985, 1995). A shortcoming of this methodology is that across different cohorts we will not observe immigrants who returned to Mexico, and only observe "survivors" from each cohort. That is, immigrants in earlier cohorts will be a subgroup of all immigrants in the cohort.
} 
Next we discuss why a decrease in the gender wage gap among Mexican immigrants can be explained with a stronger immigrant selection among women. A decrease of the gender wage gap among recent cohorts of immigrant women may be a consequence of different phenomena. For example, Figure 5B shows that the level of education of women in Mexico has increased during the last twenty years. Greater schooling for women would suggest that the average marginal productivity of Mexican women should increase relative to the marginal productivity of men. This would be true for individuals staying in Mexico and for those migrating to the U.S. As a result, we should observe not only that the gender wage gap among Mexicans in the U.S. is narrowing, but that the gender wage gap in Mexico is also decreasing. However, the data in Figure $6 \mathrm{~A}$ is not consistent with this hypothesis and shows that the gender wage gap in Mexico has increased.

Alternatively, it may be possible that as the gender wage gap increases in Mexico (as shown in Figure 6A), then high ability Mexican women will search for better opportunities and sort themselves out by migrating to the U.S. Under this scenario, as labor market opportunities worsen for women, the number of immigrant women from Mexico should increase faster than the number of immigrant men. However, this again conflicts with the results from Figure 3 which shows that the proportion of Mexican immigrant women has decreased. Yet another alternative is that during the last 20 years there has been a change in traditional gender roles in Mexico, which is manifested in higher labor market participation among Mexican women both in Mexico and the U.S. This should result in more women also migrating, which again cannot be verified with the data available to us that shows that while the raw number of immigrant women has increased, the number of immigrant men has increased faster.

Finally, as argued above,it has been widely documented (Blau and Kahn, 2006; Kuhn and Weinberger, 2010) that the gender wage gap has decreased in the United States, and it is possible that a decrease in the gender wage gap among Mexican immigrants is exclusively a consequence of a general trend in the U.S. economy. While we cannot differentiate between a decrease in the gender wage gap of Mexican immigrants to that of the secular economy, we argue that this is unlikely to be the case because the decrease in the gender wage gap is associated with stronger demand for women's labor, and this will increase the magnitude of any pull factor and will encourage more Mexican women to migrate. In addition, in our empirical strategy above we compare changes in the gender wage gap between Mexican immigrants and other Latin American

It is unclear to us whether there are any gender differences in survivorship, and for our strategy to be valid there should there should be no differences in the probability of returning to Mexico - or women should be less likely than men to return. 
immigrants. Also note that our estimators $\hat{\gamma}$ and $\hat{\beta}$ in equation 4 represent entry cohorts and include controls for year of the survey interacted with gender, which should absorb this secular trend. If the decrease in the gender wage gap among Mexican immigrants is exclusively the result of the secular trend in the U.S. economy, then our estimates for Mexican immigrants and other Latin American immigrants should be similar. If we find different estimates between these two groups then we can hypothesize that our results suggest that higher wages of Mexican immigrant women relative to men is a consequence of more stringent selection that arises due to higher migrating costs.

\section{Results}

Table 2 presents the estimates from equation (2). The sample includes only immigrants who have migrated within 5 years of each survey year. The first two columns show estimates when the response variable is an indicator of whether an immigrant is between 15 and 27 years of age, columns (3) and (4) present estimates when the response variable is whether an immigrant is in the second age category (28-37), and the last two columns show results when the response variable is whether an immigrant is in the third age category $(38+)$. The odd numbered columns are results for the sample of recent Mexican immigrants and the even numbered columns are results for the sample of recent immigrants from Latin America and the Caribbean. The difference-in-difference estimate shows gender differences in the change across time in the probability that an immigrant belongs to each age category. The difference-in-difference-in-difference estimate shows nativity differences in the change across gender and time in the probability that an immigrant belongs to each age category. A positive estimate of the triple estimate suggests that the change in the probability that a Mexican immigrant woman belongs to that age group is greater than the change in the probability for men, and that the difference across gender is greater for Mexican immigrants than the same difference for other Latin American immigrants.

The results in columns (5) and (6) of Table 2 suggest that the fraction of women from Mexico who migrate to the United States after the age of 37 is decreasing. This is in contrast to men and other Latin American immigrants, where the fraction of individuals who migrate after the age of 37 is increasing for men and women. The triple difference estimate suggests that there is decrease of two percentage points in the probability that 
an immigrant over the age of 37 is a woman from Mexico. This estimate is marginally statistically significant with a p-value of .094. In comparison, the triple estimates from the 15-27 age category and the 28-37 age category are statistically insignificant. These point estimates, while statistically insignificant, provide support for the predictions in our theoretical framework which suggest that an increase in migration cost that falls disproportionally on women will have a greater disincentive effect among older women, given that the present value of all future benefits accrued from migration are smaller than for younger migrants.

Next, we explore how migration has changed among various education categories as a result of greater border enforcement. Estimates from equation (3) are found in Table 3. Similar to Table 2, the results are presented separately for both Mexican immigrants and Latin American immigrants and for each education category (less than 9 years, 9-11 years, 12-15 years, more than 16 years). Recall that the average number of years of education for Mexican immigrant women is 10.3 years, hence the results from column (3), column (5) and column (7) will represent the right part of the education distribution. The results in column (3) and (4) suggest that the number of women who completed secundaria or middle school in Mexico is decreasing relative men with similar education, yet this difference across gender is not different from other Latin American immigrants. The results in column (5) and column (7) suggest that the fraction of Mexican immigrant women that are highly educated has increased by less than the proportion of immigrants from Latin America (in column (6) and column (8)). The estimates in column (7) suggest that the proportion of female migrants with more than twelve years of education has increased at a faster rate than the proportion of male migrants with the same education level. This finding is consistent with the rising level of schooling among women residing in Mexico.

Yet comparing the estimates for highly educated women from Mexico and other Latin American countries we see that the proportion of highly educated women from Mexico has increased at a lower pace than the proportion of other women from Latin America. These results support our theoretical prediction that since the relative returns to education are high in Mexico, an increase in migration costs that fall more heavily on women should have a stronger effect on the migration of highly educated women. Thus, given the rising level of schooling among women in Mexico coupled with the unchanged migration of highly educated women relative to men, the evidence suggests that in the face of rising migration costs, highly educated women are choosing to remain in Mexico more than women from other Latin American countries. Importantly, 
the triple difference estimator for immigrants with less than 9 years of schooling suggests that the flow of immigrants in this group has increased fastest among Mexican women than other Latin American women.

Table 4 presents the estimated differences in log wages across immigrant cohorts from equation (4). The sample includes all single immigrants and is no longer restricted to only those who have migrated within 5 years of each survey year. Columns 1 and 2 present results when no control variables are included in the wage equation. Columns 3 and 4 and columns 5 and 6 present results when control variables and occupation fixed effects are added to the estimating equation respectively. The difference-in-difference estimator shows the change in log wages across gender cohorts. The difference-in-difference-difference estimator shows the change in log wages across gender and nativity cohorts.

When demographic variables and fixed effects are included in the estimating equation, the change in log wages across gender cohorts is positive and statistically significant for Mexican immigrants and for other Latin American immigrants. This suggests that female Mexican immigrants from more recent cohorts are performing better than men in the same cohort when compared with women in earlier cohorts. In addition, the change is greater for Mexican immigrants. For example, column 6 reveals that once occupation fixed effects are added, the difference-in-difference-in-difference estimator is positive indicating that the Mexican gender wage difference has decreased by 6 percentage points faster than the wage difference for other Latin American immigrants (this is statistically significant with a p-value of 0.014). Thus, the change in log wages across gender is greater for Mexican immigrants relative to other Latin American immigrants even within the same occupations and education levels. This results suggests that demographically equivalent women from Mexico are doing better in the labor force compared to their males counterparts, and this difference is greater than that of other Latin American women.

Finally, we are interested in whether the trends we observe in Table 4 continue to hold when we evaluate changes in the gender wage gap for different age and education categories. Table 5 shows the results when we compare less educated (9 or less years of education) to highly educated immigrants (more than 9 years of education), and then we compare young immigrants (less than 30 years) to older immigrants (more than 30 years). These estimates include all demographic characteristics and occupation fixed effects. Again, because higher migrating costs will affect older and highly educated women the most, we will expect that the change in ability will be greatest among these groups, and hence the change in their hourly earnings. 
Focusing on education in columns 1-4, the difference-in-difference-in-difference estimator is positive, but statistically insignificant for less educated immigrants, but positive and statistically significant for highly educated immigrants with a p-value of .006. Suggesting, again, that highly educated Mexican immigrant women are doing better than their male counterparts, and this advantage is greater than among other Latin American immigrants. This is consistent with our theoretical prediction that the change in wages of women relative to men across cohorts should be greater for highly educated immigrants and that this change should be greater for Mexican immigrants relative to other immigrants from Latin America. However, the results are less conclusive when wages are evaluated by age categories. Columns 5-8 show that both difference-indifference-in-difference estimators are positive and the point estimate for older workers is almost twice the magnitude as for younger workers, still the triple difference is not statistically different to zero.

\section{Conclusion}

Since the 1990s, the U.S. has made considerable efforts to curb undocumented immigration. As a result of making it more difficult for migrants to cross the U.S.-Mexico border through traditional crossing channels, the costs of undocumented migration have increased. However, there is no reason to assume that these costs are the same for men and women. Women are more vulnerable to the physical dangers of crossing the border illegally and as the number of female-headed households in Mexico continues to grow, they are also more likely than men to make multiple trips across the border.

In this paper, we have examined the extent to which an increase in the costs of crossing the border has affected the composition of Mexican immigrant women relative to men. While we are unable to measure the direct impact of border costs on the selection of undocumented immigrants, we propose a set of theoretical predictions based on a standard model of the decision to migrate and examine the extent to which these theoretical predictions are observed in the migration and wage patterns of Mexican immigrants. In particular, we predicted that an increase in migration costs would result in the proportion of female immigrants to decline, and with a larger decrease for older and highly educated immigrants relative to younger and less educated immigrants.

Estimates from our probability equations provide evidence in support of these predictions. In order 
to provide additional evidence of the changing composition of Mexican immigrant women relative to men, we also examined the change in the gender wage differences across immigrant cohorts. We find evidence that supports our prediction that wages among Mexican women are growing faster than wages of men, and this difference is greater than among other Latin American immigrants. In addition, we find evidence that wages of women in the groups most vulnerable to border enforcement, older and highly educated women, have increased faster than the wages of their males counterparts and again differences are greatest among Mexican immigrants. 


\section{References}

[1] Manuela Angelucci. "U.S. border enforcement and the net flow of Mexican illegal migration". IZA Discussion Paper Series 1642, 2005.

[2] Francine Blau and Lawrence Kahn. "The U.S. gender pay gap in the 1990s: Slowing convergence". Industrial and Labor Relations Review, 60(1):45-66, 2006.

[3] Francine Blau and Lawrence Kahn. Gender and Assimilation Among Mexican Americans, pages 57-106. The University of Chicago Press, Chicago, 2007.

[4] George Borjas. "Self-selection and the earnings of immigrants". American Economic Review, $77(4): 531-553,1987$.

[5] Daniel Chiquiar and Gordon Hanson. "International migration, self-selection, and the distribution of wages: Evidence from Mexico and the United States". Journal of Political Economy, 113(2):239-281, 2005.

[6] Deborah A. Cobb-Clark. "Immigrant selectivity and wages: The evidence for women". American Economic Review, 83(4):986-993, 1993.

[7] Katherine Donato and Evelyn Patterson. "Women and Men on the Move: Undocumented Border Crossing", pages 111-130. The Russell Sage Foundation, New York, NY, 2004.

[8] K. Eschbach, JM Hagan, and NP Rodriguez. "Deaths during undocumented migration: Trends and policy implications in the new era of homeland security". Defense of the Alien, 26:37-52, 2003.

[9] Sylvanna Falcon. "Rape asa weapon of war: Advancing human rights for women at the U.S.-Mexico border". Social Justice, 28(2):31-51, 2001.

[10] Alicia Giron. "Circuitos financieros y laborales transfronterizos". Problemas del Desarrollo Revista Latinomamericana de Economia, 38(151):63-86, 2007.

[11] Gordon Hanson. "Illegal migration from Mexico to the united states". Journal of Economic Literature, 44(December):869-924, 2006. 
[12] Tyche Hendricks. "On the border". San Francisco Chronicle, 2007.

[13] Pierrette Hondagneu-Sotelo and Ernestine Avila. "I'm Here, But I'm There: The Meaning of Latina Transnational Motherhood", pages 254-265. Stanford University Press, Stanford, 2007.

[14] Gladys Lopez-Acevedo. "Mexico: Two decades of the evolution of education and inequality". World Bank Policy Research Working Paper 3919, 2006.

[15] Enrico Marcelli and Wayne Cornelius. "The changing profile of mexican migrants to the United States: New evidence from California and Mexico". Latin American Research Review, 36(3):105-131, 2001.

[16] General Accounting Office. "Illegal immigration". Technical report.

[17] Claudia Olivetti and Barbara Petrongolo. "Unequal pay or unequal employment? a cross country analysis of gender gaps". Journal of Labor Economics, 26(4):621-654, 2008.

[18] Jeffrey Passel. "Estimates of the size and characteristics of the undocumented population". Technical report, Pew Hispanic Center: Washington, DC, March 2005.

[19] Jeffrey Passel and D'Vera Cohn. "Trends in unauthorized immigration: Undocumented inflow now trails legal inflow". Technical report, Pew Hispanic Center: Washington, DC, October 2008.

[20] Belinda Reyes. "Immigrant trip duration: The case of immigrants from western Mexico". International Migration Review, 35(4):1185-1204, 2001.

[21] Todd Sorensen and Carmen Carrion-Flores. "The effects of border enforcement on migrants, border crossing choice: Diversion or deterrence". Working Paper, 2006.

[22] Oded Stark and J. Edward Taylor. "Relative deprivation and international migration". Demography, 26(1):1-14, 1989.

[23] Catherine J. Weinberger and Peter J. Kuhn. "Changing levels or changing slopes? The narrowing of the U.S. gender earnings gap, 1959-1999". Industrial and Labor Relations Review, 63(3):384-406, 2010. 
Figure 1

Coyote Costs and Duration of Stay for Mexican Immigrants

Figure A: Coyote Costs

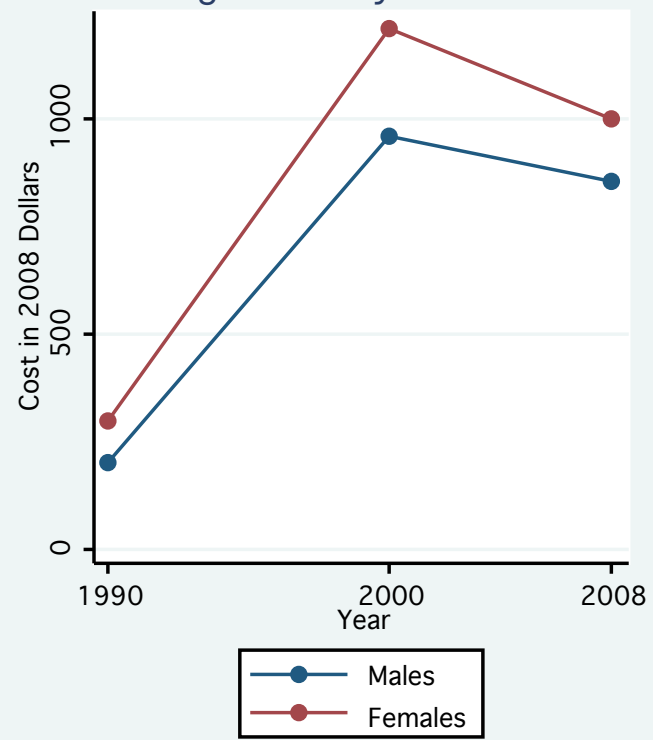

Source: Mexican Migration Project.

Sample: Undocumented immigrants.
Figure B: Duration of Trip

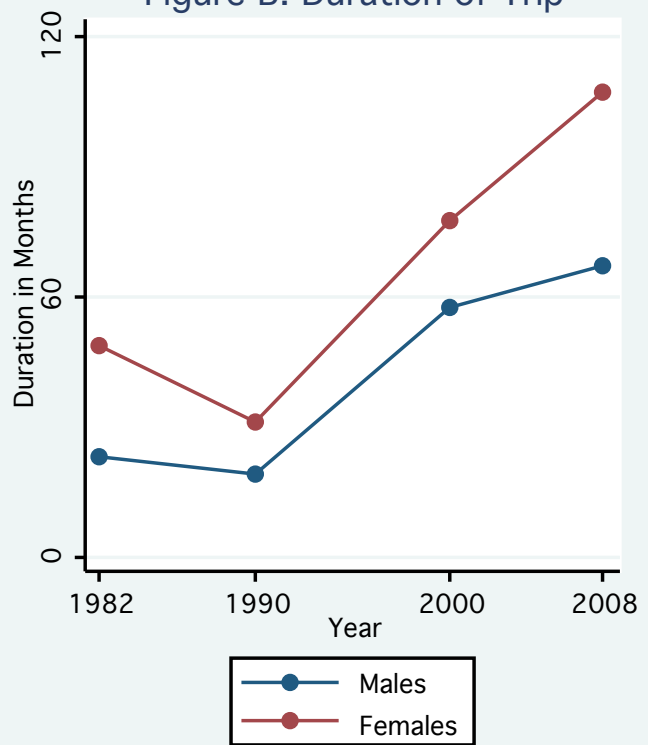

Source: Mexican Migration Project. Sample: Undocmented immigrants. 
Figure 2
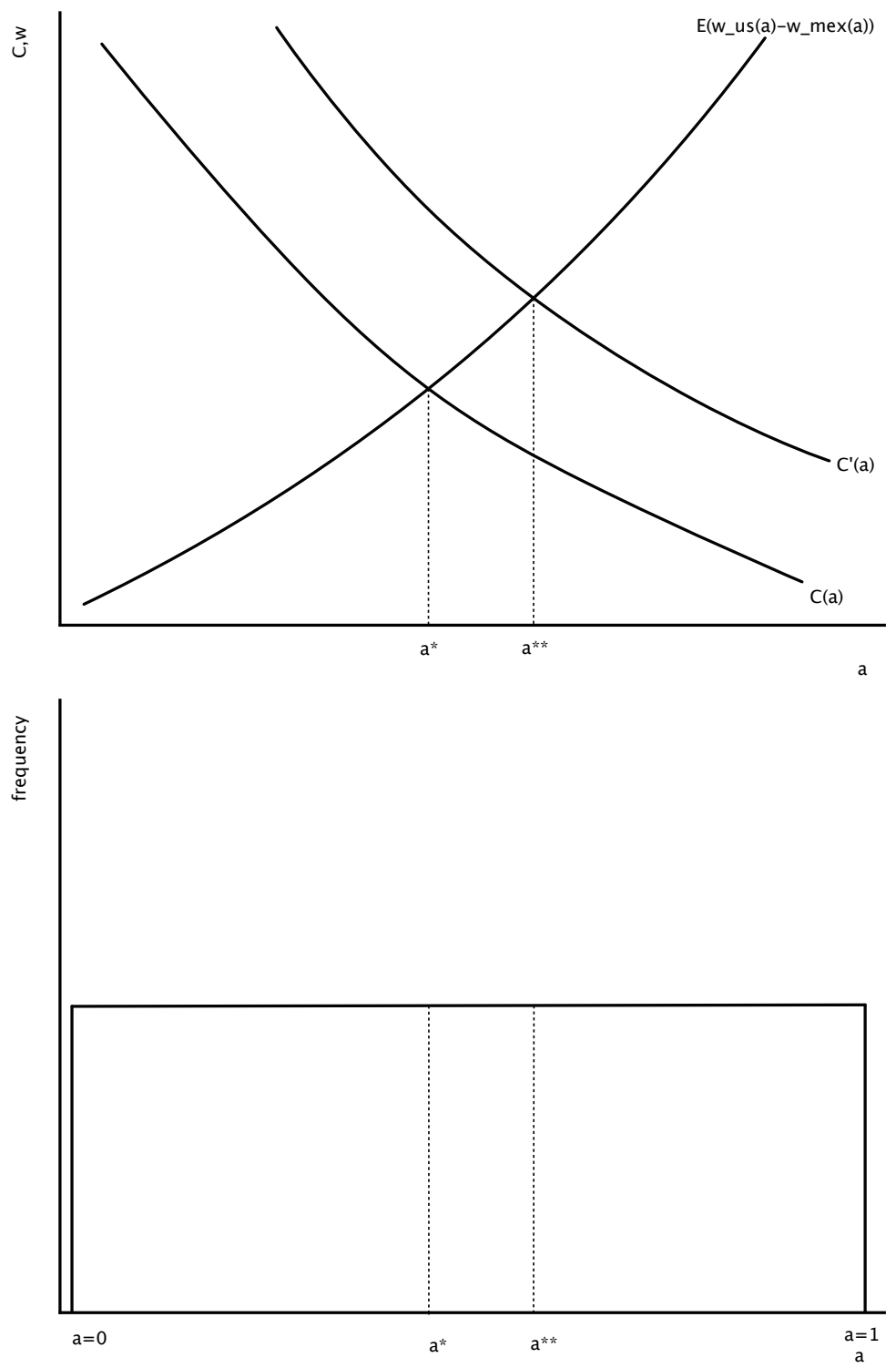


\section{Figure 3}

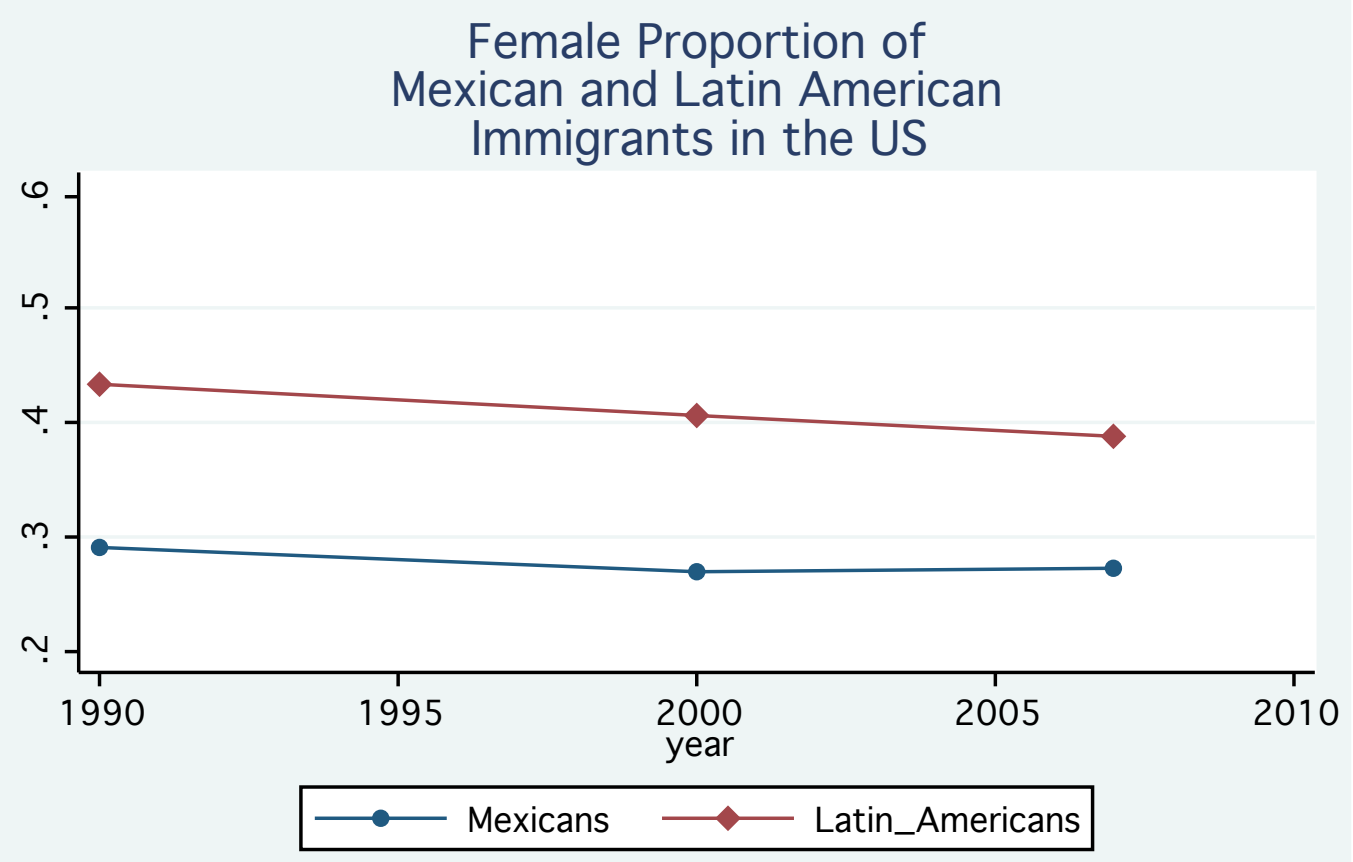

Source: 1990 and 2000 Census; 2006-2008 American Community Survey. Sample: Single immigrants who arrived within 5 years of the survey year. 
Figure 4

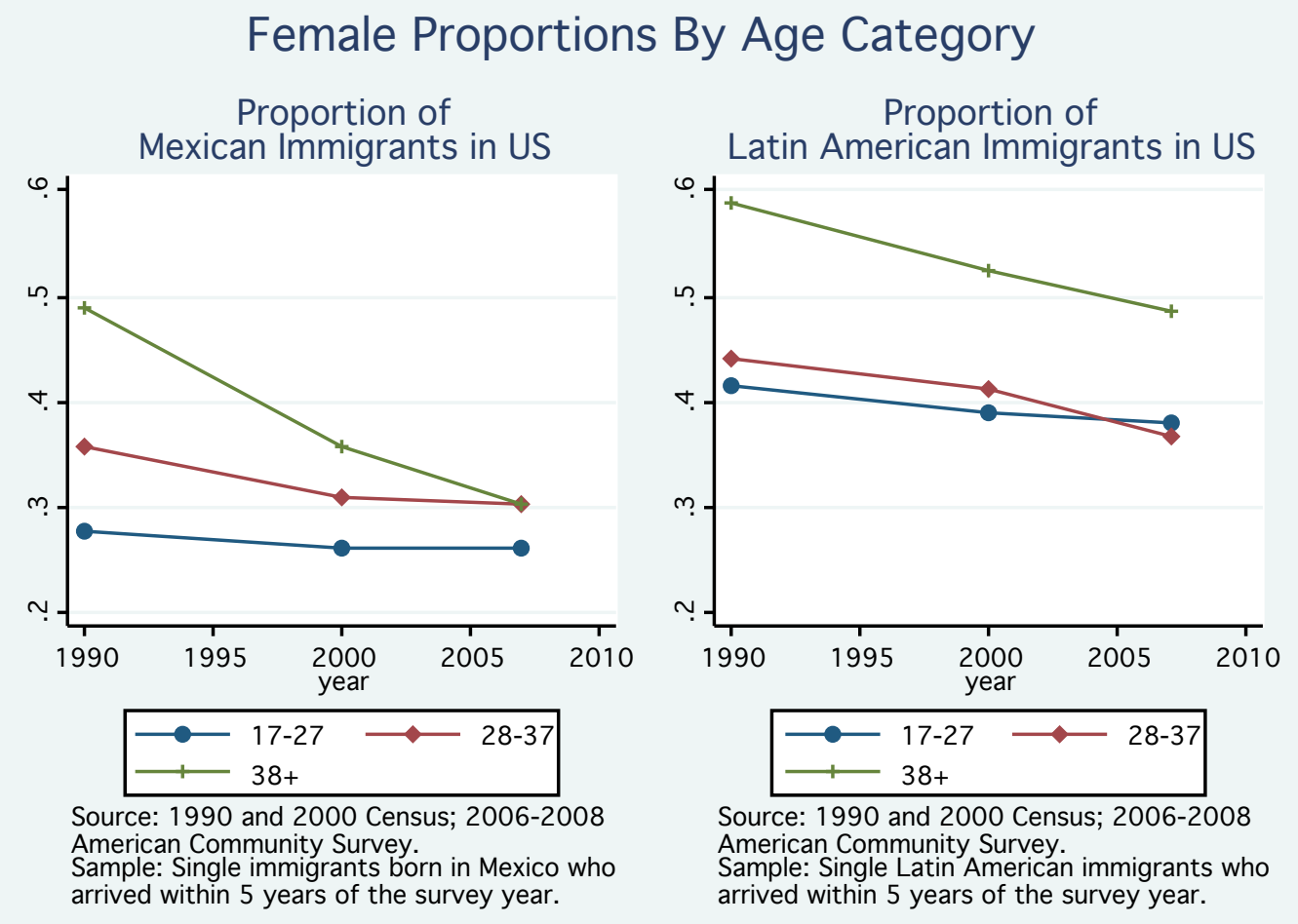


Figure 5

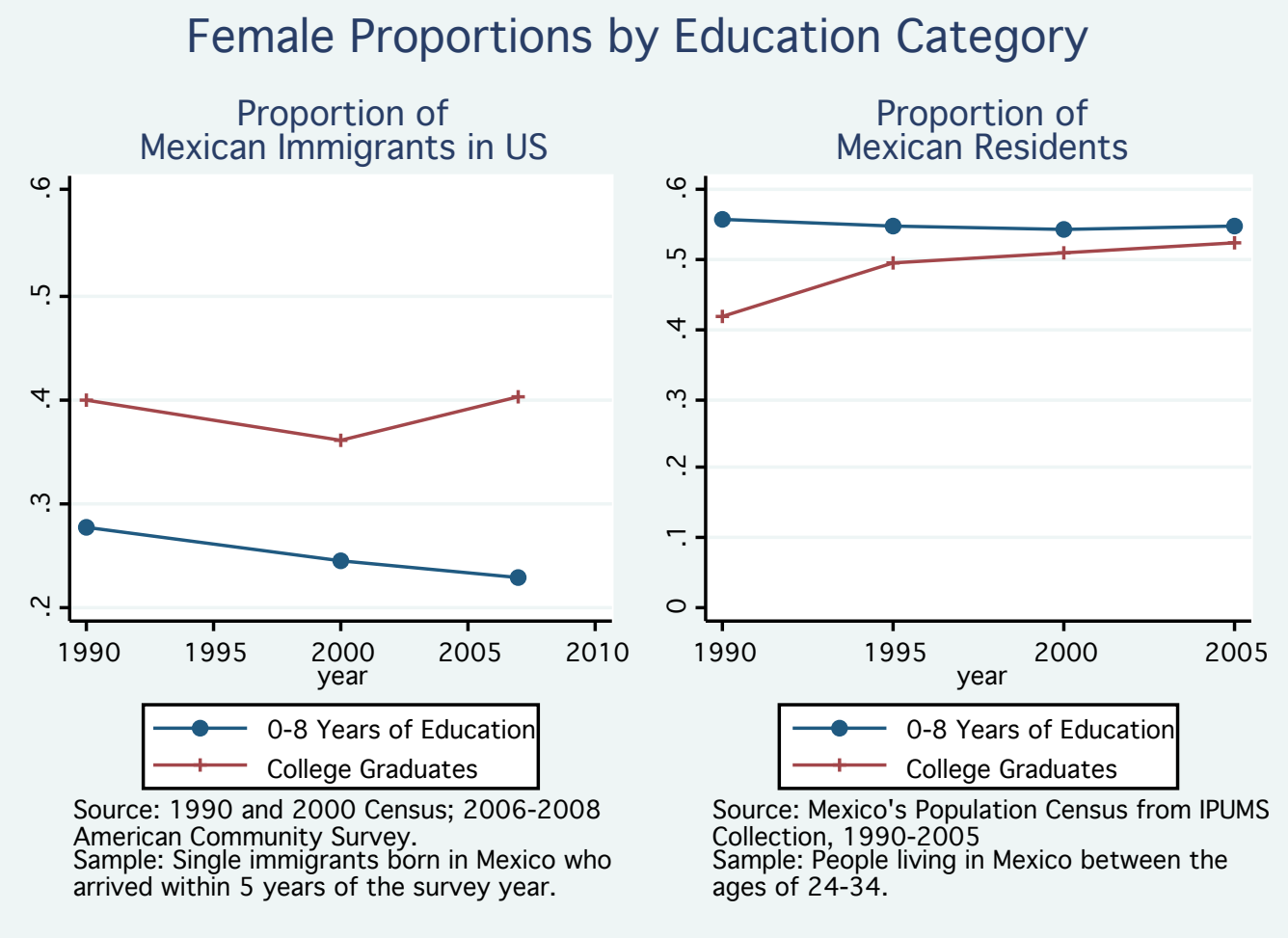




\section{Figure 6}

\section{Earnings and Employment Gender Gaps of Mexican Workers}

Recent Mexican Immigrants in U.S.

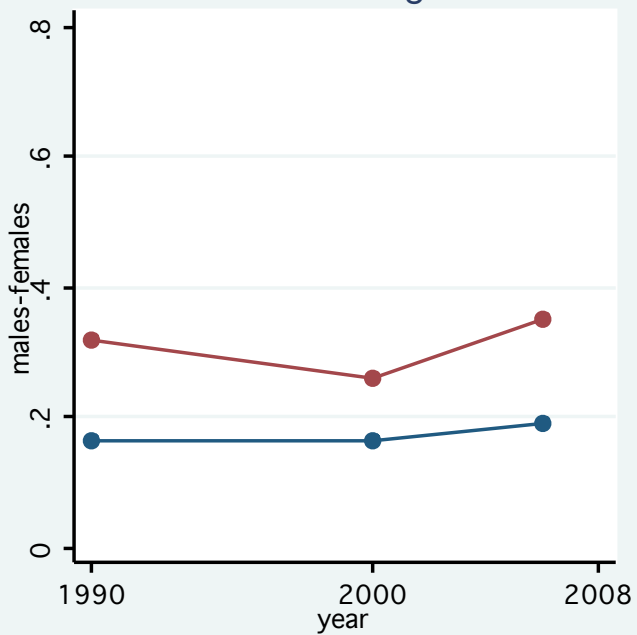

$\longrightarrow$ log Hourly Wage Employment/Population

1990, 2000 Decennial Census and 2007-2008 ACS

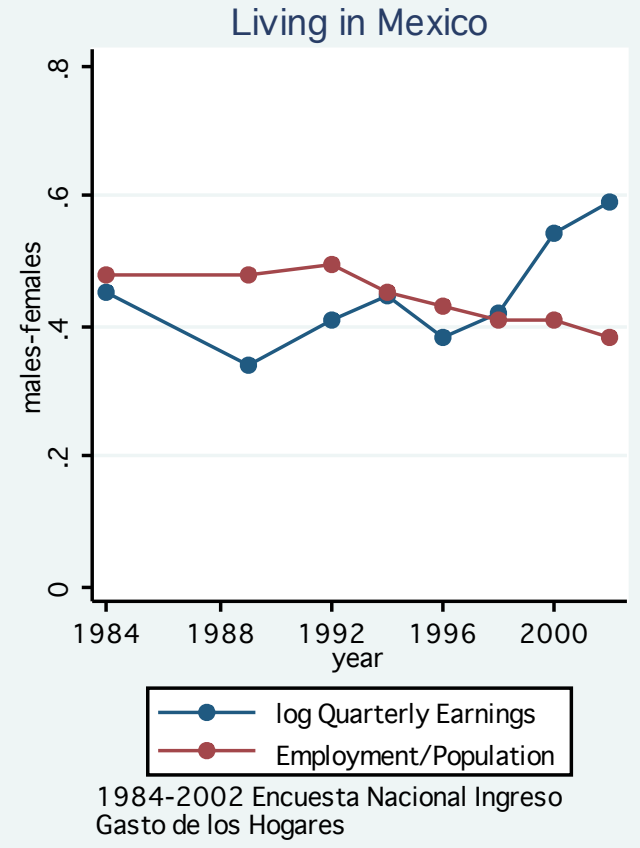


Table 1: Summary Statistics for Immigrants

\begin{tabular}{|c|c|c|c|c|}
\hline & \multicolumn{2}{|c|}{$\begin{array}{c}\text { Mexican } \\
\text { Immigrants }\end{array}$} & \multicolumn{2}{|c|}{$\begin{array}{c}\text { Latin American } \\
\text { Immigrants }\end{array}$} \\
\hline & $\begin{array}{l}\text { Men } \\
(1)\end{array}$ & $\begin{array}{l}\text { Women } \\
(2)\end{array}$ & $\begin{array}{c}\text { Men } \\
(3)\end{array}$ & $\begin{array}{l}\text { Women } \\
\text { (4) }\end{array}$ \\
\hline log Hourly Wage & $\begin{array}{l}1.555 \\
(0.000)\end{array}$ & $\begin{array}{l}1.462 \\
(0.001)\end{array}$ & $\begin{array}{l}1.734 \\
(0.001)\end{array}$ & $\begin{array}{c}1.631 \\
(0.001)\end{array}$ \\
\hline Employed & $\begin{array}{c}0.801 \\
(0.000)\end{array}$ & $\begin{array}{c}0.378 \\
(0.000)\end{array}$ & $\begin{array}{c}0.742 \\
(0.000)\end{array}$ & $\begin{array}{c}0.526 \\
(0.000)\end{array}$ \\
\hline Years of Schooling & $\begin{array}{l}10.238 \\
(0.002)\end{array}$ & $\begin{array}{l}10.340 \\
(0.003)\end{array}$ & $\begin{array}{l}11.795 \\
(0.003)\end{array}$ & $\begin{array}{l}12.197 \\
(0.003)\end{array}$ \\
\hline Age & $\begin{array}{l}28.216 \\
(0.005)\end{array}$ & $\begin{array}{l}29.749 \\
(0.007)\end{array}$ & $\begin{array}{l}31.394 \\
(0.008)\end{array}$ & $\begin{array}{l}32.973 \\
(0.009)\end{array}$ \\
\hline Single & $\begin{array}{c}0.523 \\
(0.000)\end{array}$ & $\begin{array}{c}0.305 \\
(0.000)\end{array}$ & $\begin{array}{c}0.503 \\
(0.000)\end{array}$ & $\begin{array}{c}0.370 \\
(0.000)\end{array}$ \\
\hline Married & $\begin{array}{c}0.436 \\
(0.000)\end{array}$ & $\begin{array}{c}0.605 \\
(0.000)\end{array}$ & $\begin{array}{c}0.428 \\
(0.000)\end{array}$ & $\begin{array}{c}0.496 \\
(0.000)\end{array}$ \\
\hline Observations & 98,738 & 67,781 & 55,665 & 54,579 \\
\hline \multicolumn{5}{|c|}{$\begin{array}{l}\text { Notes: Sample includes immigrants between the ages of } 18-64 \\
\text { who have been in the U.S. for } 5 \text { years or less. Standard errors } \\
\text { in parentheses. } \\
\text { Source: } 1990 \text { and } 2000 \text { Census and 2006-2008 American } \\
\text { Community Survey }\end{array}$} \\
\hline
\end{tabular}


Table 2: Recent Immigrants in the U.S. by Age Category

\begin{tabular}{|c|c|c|c|c|c|c|}
\hline & \multicolumn{2}{|c|}{$15-27$ years } & \multicolumn{2}{|c|}{$28-37$ years } & \multicolumn{2}{|c|}{$37+$ years } \\
\hline & $\begin{array}{c}\text { Mexicans } \\
(1)\end{array}$ & $\begin{array}{c}\text { Other Latin } \\
\text { Americans } \\
(2)\end{array}$ & $\begin{array}{c}\text { Mexicans } \\
(3)\end{array}$ & $\begin{array}{c}\text { Other Latin } \\
\text { Americans } \\
(4)\end{array}$ & $\begin{array}{c}\text { Mexicans } \\
(5) \\
\end{array}$ & $\begin{array}{c}\text { Other Latin } \\
\text { Americans } \\
(6)\end{array}$ \\
\hline fem $\times 1990$ & $\begin{array}{c}0.139 \\
(0.006)\end{array}$ & $\begin{array}{c}0.003 \\
(0.007)\end{array}$ & $\begin{array}{l}-0.074 \\
(0.006)\end{array}$ & $\begin{array}{c}0.001 \\
(0.006)\end{array}$ & $\begin{array}{l}-0.065 \\
(0.004)\end{array}$ & $\begin{array}{c}-0.005 \\
(0.005)\end{array}$ \\
\hline fem $\times 2000$ & $\begin{array}{c}0.086 \\
(0.006)\end{array}$ & $\begin{array}{l}-0.034 \\
(0.007)\end{array}$ & $\begin{array}{l}-0.035 \\
(0.005)\end{array}$ & $\begin{array}{c}0.018 \\
(0.006)\end{array}$ & $\begin{array}{l}-0.050 \\
(0.003)\end{array}$ & $\begin{array}{c}0.016 \\
(0.004)\end{array}$ \\
\hline fem $\times 2007$ & $\begin{array}{l}-0.014 \\
(0.009)\end{array}$ & $\begin{array}{l}-0.084 \\
(0.010)\end{array}$ & $\begin{array}{c}0.050 \\
(0.009)\end{array}$ & $\begin{array}{c}0.044 \\
(0.009)\end{array}$ & $\begin{array}{l}-0.036 \\
(0.005)\end{array}$ & $\begin{array}{c}0.039 \\
(0.007)\end{array}$ \\
\hline male $\times 1990$ & & $\begin{array}{l}-0.202 \\
(0.005)\end{array}$ & & $\begin{array}{c}0.103 \\
(0.005)\end{array}$ & & $\begin{array}{c}0.099 \\
(0.004)\end{array}$ \\
\hline male $\times 2000$ & $\begin{array}{l}-0.056 \\
(0.004)\end{array}$ & $\begin{array}{l}-0.231 \\
(0.005)\end{array}$ & $\begin{array}{c}0.033 \\
(0.004)\end{array}$ & $\begin{array}{c}0.093 \\
(0.004)\end{array}$ & $\begin{array}{c}0.024 \\
(0.003)\end{array}$ & $\begin{array}{c}0.137 \\
(0.004)\end{array}$ \\
\hline male $\times 2007$ & $\begin{array}{l}-0.173 \\
(0.005)\end{array}$ & $\begin{array}{l}-0.283 \\
(0.006)\end{array}$ & $\begin{array}{c}0.100 \\
(0.005)\end{array}$ & $\begin{array}{c}0.117 \\
(0.006)\end{array}$ & $\begin{array}{c}0.073 \\
(0.004)\end{array}$ & $\begin{array}{c}0.167 \\
(0.005)\end{array}$ \\
\hline $\begin{array}{l}\text { diff-in-diff estimate } \\
\text { p value }\end{array}$ & $\begin{array}{l}0.020 \\
0.094\end{array}$ & $\begin{array}{c}-0.006 \\
0.667\end{array}$ & $\begin{array}{l}0.024 \\
0.023\end{array}$ & $\begin{array}{l}0.030 \\
0.012\end{array}$ & $\begin{array}{c}-0.044 \\
0.000\end{array}$ & $\begin{array}{c}-0.024 \\
0.012\end{array}$ \\
\hline $\begin{array}{l}\text { diff-in-diff-in-diff estimate } \\
\text { p value }\end{array}$ & \multicolumn{2}{|c|}{0.025} & \multicolumn{2}{|c|}{-0.005} & \multicolumn{2}{|c|}{-0.020} \\
\hline
\end{tabular}

Notes Sample includes single, adult, immigrants between the ages of 18-64 who have been in the U.S. for 5 years or less. The diff-in-diff estimate is fem $\times 2007$-fem $\times 1990$-male $\times 2007$. The diff-in-diff-diff estimate is the diff-in-diff estimate for Mexican immigrants minus the diff-in-diff estimate for Latin American immigrants. Standard errors in parentheses.

Source: 1990 and 2000 Census and 2006-2008 American Community Survey 


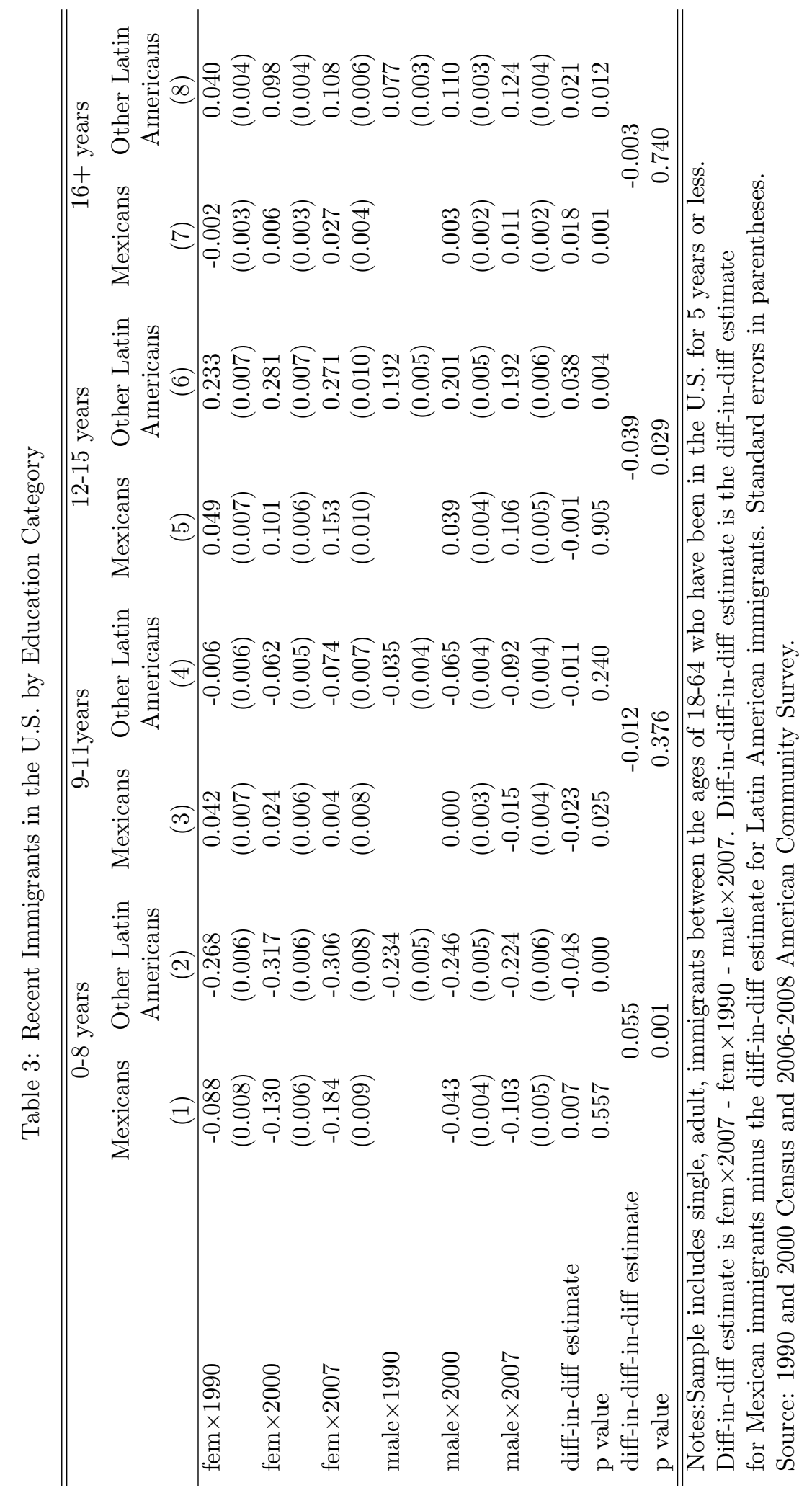


Table 4: Ordinary Least Suqares: Dependent Variable Log Hourly Earnings

\begin{tabular}{|c|c|c|c|c|c|c|}
\hline & $\begin{array}{c}\text { Mexicans } \\
\text { (1) }\end{array}$ & $\begin{array}{c}\text { Latin } \\
\text { Americans } \\
(2)\end{array}$ & Mexicans & $\begin{array}{c}\text { Latin } \\
\text { Americans } \\
(4)\end{array}$ & Mexicans & $\begin{array}{c}\text { Latin } \\
\text { Americans } \\
(6)\end{array}$ \\
\hline fem*1984 & $\begin{array}{c}-0.333 \\
(0.009)\end{array}$ & $\begin{array}{c}0.031 \\
(0.009)\end{array}$ & $\begin{array}{l}-0.324 \\
(0.009)\end{array}$ & $\begin{array}{c}-0.104 \\
(0.008)\end{array}$ & $\begin{array}{l}-0.256 \\
(0.009)\end{array}$ & $\begin{array}{c}-0.128 \\
(0.008)\end{array}$ \\
\hline fem*1984-1987 & $\begin{array}{l}-0.438 \\
(0.011)\end{array}$ & $\begin{array}{l}-0.153 \\
(0.011)\end{array}$ & $\begin{array}{l}-0.282 \\
(0.012)\end{array}$ & $\begin{array}{l}-0.112 \\
(0.010)\end{array}$ & $\begin{array}{l}-0.224 \\
(0.011)\end{array}$ & $\begin{array}{l}-0.117 \\
(0.010)\end{array}$ \\
\hline fem*1988-1991 & $\begin{array}{l}-0.437 \\
(0.010)\end{array}$ & $\begin{array}{l}-0.223 \\
(0.011)\end{array}$ & $\begin{array}{l}-0.249 \\
(0.011)\end{array}$ & $\begin{array}{l}-0.135 \\
(0.011)\end{array}$ & $\begin{array}{l}-0.202 \\
(0.010)\end{array}$ & $\begin{array}{l}-0.143 \\
(0.010)\end{array}$ \\
\hline fem*1992-1996 & $\begin{array}{l}-0.388 \\
(0.014)\end{array}$ & $\begin{array}{l}-0.181 \\
(0.015)\end{array}$ & $\begin{array}{l}-0.221 \\
(0.015)\end{array}$ & $\begin{array}{l}-0.129 \\
(0.015)\end{array}$ & $\begin{array}{l}-0.166 \\
(0.014)\end{array}$ & $\begin{array}{l}-0.138 \\
(0.014)\end{array}$ \\
\hline fem*1995-1997 & $\begin{array}{l}-0.434 \\
(0.012)\end{array}$ & $\begin{array}{l}-0.189 \\
(0.014)\end{array}$ & $\begin{array}{l}-0.150 \\
(0.013)\end{array}$ & $\begin{array}{l}-0.021 \\
(0.015)\end{array}$ & $\begin{array}{l}-0.109 \\
(0.013)\end{array}$ & $\begin{array}{l}-0.053 \\
(0.014)\end{array}$ \\
\hline fem*1998-1999 & $\begin{array}{l}-0.463 \\
(0.011)\end{array}$ & $\begin{array}{l}-0.289 \\
(0.013)\end{array}$ & $\begin{array}{l}-0.163 \\
(0.013)\end{array}$ & $\begin{array}{l}-0.105 \\
(0.014)\end{array}$ & $\begin{array}{l}-0.116 \\
(0.012)\end{array}$ & $\begin{array}{l}-0.109 \\
(0.013)\end{array}$ \\
\hline fem*2000+ & $\begin{array}{l}-0.538 \\
(0.013)\end{array}$ & $\begin{array}{l}-0.357 \\
(0.016)\end{array}$ & $\begin{array}{l}-0.177 \\
(0.015)\end{array}$ & $\begin{array}{l}-0.099 \\
(0.017)\end{array}$ & $\begin{array}{l}-0.128 \\
(0.015)\end{array}$ & $\begin{array}{l}-0.092 \\
(0.016)\end{array}$ \\
\hline male*1984 & & $\begin{array}{c}0.246 \\
(0.004)\end{array}$ & & $\begin{array}{l}0.108 \\
(0.004)\end{array}$ & & $\begin{array}{c}0.062 \\
(0.004)\end{array}$ \\
\hline male*1984-1987 & $\begin{array}{c}-0.136 \\
(0.004)\end{array}$ & $\begin{array}{c}0.064 \\
(0.005)\end{array}$ & $\begin{array}{c}-0.017 \\
(0.005)\end{array}$ & $\begin{array}{c}0.071 \\
(0.006)\end{array}$ & $\begin{array}{c}-0.016 \\
(0.005)\end{array}$ & $\begin{array}{c}0.032 \\
(0.005)\end{array}$ \\
\hline male*1988-1991 & $\begin{array}{l}-0.169 \\
(0.004)\end{array}$ & $\begin{array}{c}0.003 \\
(0.005)\end{array}$ & $\begin{array}{l}-0.016 \\
(0.005)\end{array}$ & $\begin{array}{c}0.052 \\
(0.006)\end{array}$ & $\begin{array}{l}-0.021 \\
(0.005)\end{array}$ & $\begin{array}{c}0.012 \\
(0.006)\end{array}$ \\
\hline male*1992-1996 & $\begin{array}{l}-0.177 \\
(0.005)\end{array}$ & $\begin{array}{c}0.001 \\
(0.007)\end{array}$ & $\begin{array}{l}-0.001 \\
(0.007)\end{array}$ & $\begin{array}{c}0.061 \\
(0.008)\end{array}$ & $\begin{array}{l}-0.011 \\
(0.007)\end{array}$ & $\begin{array}{c}0.021 \\
(0.008)\end{array}$ \\
\hline male*1995-1997 & $\begin{array}{l}-0.236 \\
(0.005)\end{array}$ & $\begin{array}{l}-0.061 \\
(0.007)\end{array}$ & $\begin{array}{c}0.043 \\
(0.008)\end{array}$ & $\begin{array}{c}0.103 \\
(0.009)\end{array}$ & $\begin{array}{c}0.020 \\
(0.007)\end{array}$ & $\begin{array}{c}0.053 \\
(0.008)\end{array}$ \\
\hline male*1998-1999 & $\begin{array}{l}-0.297 \\
(0.005)\end{array}$ & $\begin{array}{l}-0.094 \\
(0.007)\end{array}$ & $\begin{array}{c}0.005 \\
(0.008)\end{array}$ & $\begin{array}{c}0.080 \\
(0.009)\end{array}$ & $\begin{array}{l}-0.014 \\
(0.007)\end{array}$ & $\begin{array}{c}0.032 \\
(0.009)\end{array}$ \\
\hline male*2000+ & $\begin{array}{l}-0.330 \\
(0.006)\end{array}$ & $\begin{array}{l}-0.175 \\
(0.008)\end{array}$ & $\begin{array}{c}0.042 \\
(0.010)\end{array}$ & $\begin{array}{c}0.089 \\
(0.011)\end{array}$ & $\begin{array}{c}0.013 \\
(0.010)\end{array}$ & $\begin{array}{c}0.039 \\
(0.011)\end{array}$ \\
\hline demographic variables & no & no & yes & yes & yes & yes \\
\hline fixed effects & no & no & no & no & yes & yes \\
\hline diff-in-diff & 0.125 & 0.033 & 0.104 & 0.024 & 0.116 & 0.059 \\
\hline p-value & 0.000 & 0.095 & 0.000 & 0.189 & 0.000 & 0.001 \\
\hline diff-in-diff-in-diff & \multicolumn{2}{|c|}{0.092} & \multicolumn{2}{|c|}{0.080} & \multicolumn{2}{|c|}{0.057} \\
\hline p-value & \multicolumn{2}{|c|}{0.000} & \multicolumn{2}{|c|}{0.001} & \multicolumn{2}{|c|}{0.014} \\
\hline R-square & \multicolumn{2}{|c|}{0.098} & \multicolumn{2}{|c|}{0.198} & \multicolumn{2}{|c|}{0.278} \\
\hline $\mathrm{N}$ & \multicolumn{2}{|c|}{425,813} & \multicolumn{2}{|c|}{425,813} & \multicolumn{2}{|c|}{425,813} \\
\hline
\end{tabular}

Notes: Sample includes single, adult, immigrants between the ages of 18-64. The diff-in-diff estimate is fem*2000-fem*1984-male*2000. The diff-in-diff-diff estimate is the diff-in-diff estimate for Mexican immigrants minus the diff-in-diff estimate for other Latin American immigrants. Standard errors in parentheses.

Source: 1990 and 2000 Census and 2006-2008 American Community Survey 


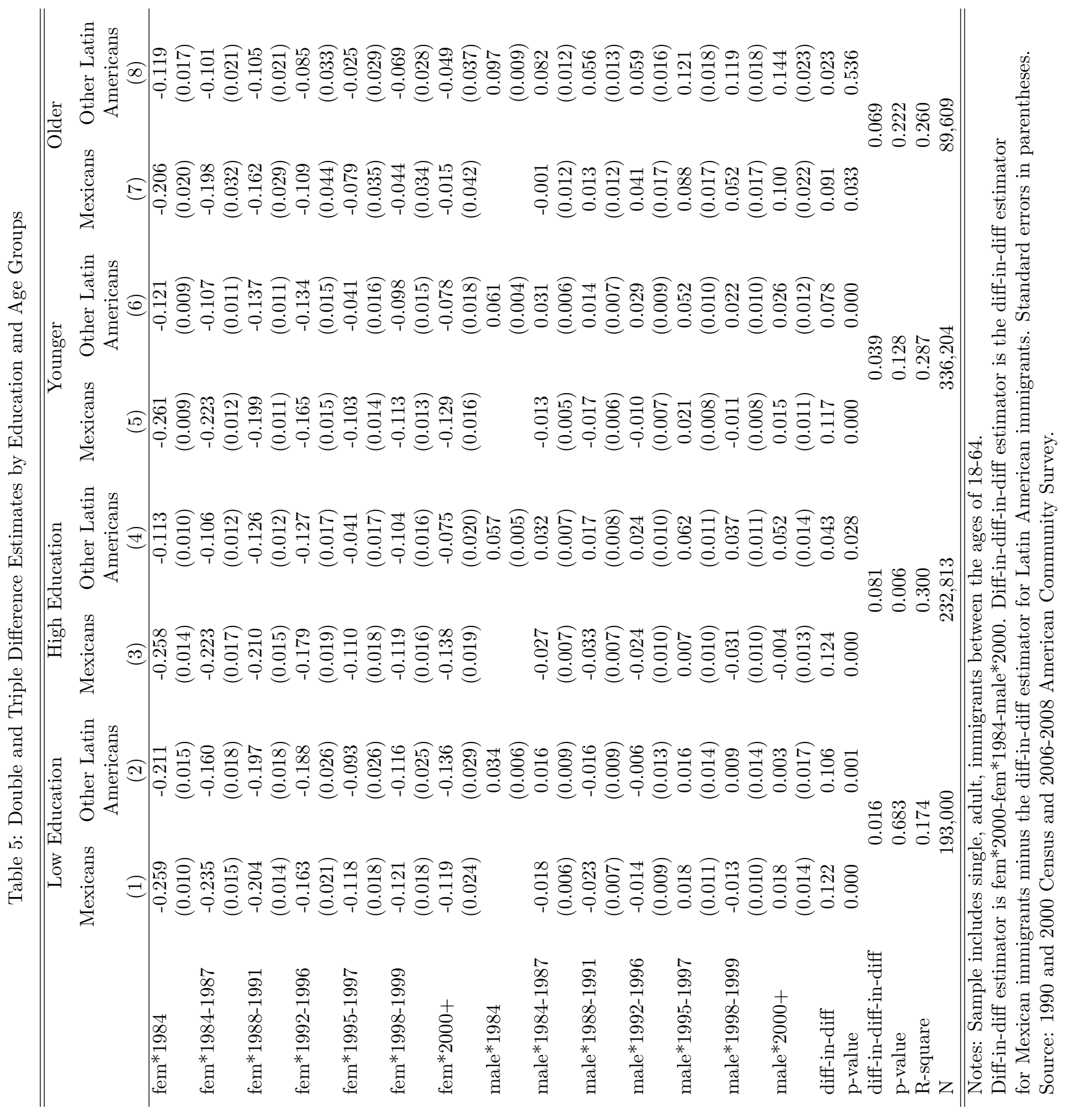

